\title{
Demographics In Civil Trials: Biases And Implications
}

James H. Underwood, III, University of Louisiana, Lafayette, USA

Denis Oris Boudreaux, University of Louisiana, USA

Spuma Rao, University of Louisiana, USA

\begin{abstract}
This paper investigates the implications of the demographics of jury members and its influence on their findings. A written civil case where the defendant was at fault but the damage and injury claims were equally believable on both sides was presented to a random group of potential jurors. A survey instrument collected selected demographic information from participants and asked how they would rule as to injury and damage awards were they jurors in the case. The sample was then analyzed as to the difference in their finding of fault and award recommendation based on the jurors' selected demographic characteristics. Findings indicate that a juror's recommendation regarding medical expense award and business damage award is not independent of gender and race.
\end{abstract}

Keywords: Jury Demographics, Jury Selection, Juror Characteristics, Juror Race, Juror Ethnicity, Juror sex, Juror Gender, Juror Bias, Civil Court Decisions

\section{INTRODUCTION}

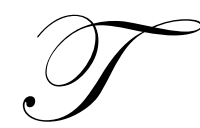

industry defendant.

rials are much too important to be decided by juries." This tagline for the 2003 film Runaway Jury emphasizes how important the right jury is to the outcome of a civil trial. In the movie, actor Gene Hackman plays a jury selection expert with the job of selecting the jury to assure a win for the gun-

Attorneys go to great effort to pick the "right" jury, as each side seeks to seat jurors it believes will favor its side and will more readily accept its evidence, explanation and claims to be true. Attorneys question potential jurors about their beliefs, lifestyles, and experiences to discover potential biases. Many also apply their own concepts of the possible relationship of jurors' demographic characteristics to juror decision making in seating acceptable ones. The purpose of this paper is to investigate if jury demographics can make a difference in civil rulings and court decisions. The study entailed presenting a written case concerning an automobile accident to 400 people of very diverse backgrounds. After receiving specific oral instructions respondents read the case and completed a survey instrument. The survey asked respondents to identify certain of their demographic characteristics and how they would have decided or voted with respect to damage awards were they a member of the jury in the case. We then analyzed the data for differences by respondent characteristics. The paper is organized as follows: the first section summarizes findings from criminal and civil jury literature about the relationship between jury demographics and verdicts; the second describes the case presented to participants; the third presents the findings of the research; and the fourth summarizes and discusses implications of the findings.

\section{EVIDENCE FROM LITERATURE}

In criminal trials, jury selection is the most important part of the trial (Faringer 1980). The process of voir dire enables attorneys to gather information so they can make informed judgments about jurors and their biases. The attorneys' goal is to seat jurors they believe will produce results desired. Attorneys generally believe that demographic, cognitive, and behavioral characteristics of jurors will influence their deliberations, judgments, and the ultimate verdict (pp 120-121). Turner (1996) reviews the conceptual foundations for these beliefs and cites a number of studies in support including Krieger (1995), Kennedy (1994), Pennington and Hastie (1991) and Ugwuegbu (1973), among others. 
Attorneys often use checklists that catalog relevant topics of inquiry to help them make enlightened selections. Such checklists usually include questions related to family status and children, home ownership, occupation, education, military or law enforcement service, experience with the justice system, media consumption habits, organizational affiliation and the like (pp.123-128). See also Ginger (1979), Kennelly(1965), Schulman (1973), and Bonora and Krauss (1979) for similar checklists and guides.

A substantial body of literature presents mixed evidence of the effects of juror's demographic characteristics on trial outcomes. Visher (1987), citing works by Hans and Vidmar (1982), Hastie, Penrod et al. (1983), and Hepburn (1980) point out that while juror demographic characteristics-- age, gender, race, occupation--are statistically related to jurors' judgments of the defendant, they are not strong enough to predict verdicts (p.3). Visher's 1987 study of 331 jurors in 38 sexual assault trials revealed that jurors' demographics-- age, race and sex-- seem unrelated to judgments of defendant guilt; psychographic variables, however, such as juror beliefs in the need for harsher sentences and stricter laws increased the likelihood of guilty verdicts.

Golding and co-authors (Golding, Bradshaw et al. 2007) show gender composition affects deliberations and may affect jury level decision-making processes in child abuse cases and that gender affects perceptions of elder abuse (Golding, Yozwiak et al. 2005). Higgins and Heath (2007) report that mock juror age affects verdicts and sentences in cases where the excuse defense was highly self-inflicted. In criminal cases where the insanity defense may apply, Breheney et al (2007) show juror gender may make a difference in verdict, although the dynamics of gender effects needs further research.

King's (1991), review cites a number of studies that show racial composition of juries changes verdicts, including those by Alschuler ( 1989), Johnson (1985), Underwood (1992), Miller (1978), Ugwuegbu (1979), Mills (1980), and Lipton (1983). Collectively, these studies show that the extent to which race impacts the verdict depends on a number of factors including, defendant's and victim's race, strength of evidence, case attributes (e.g., racially charged issues, black versus white parties, rights-active parties, attorneys' race, indictments and sentences), and jury racial heterogeneity. Taylor-Thompson (2000) likewise presents evidence and arguments that race and gender impact jury deliberations and can materially affect outcomes in both criminal and civil trials.

There are differences in the jury selection for criminal cases and civil cases. Jurors historically have vast freedom in the process for assessing damages and establishing compensation in civil trials (Greene 1989). Jurors' competence, predispositions, and biases are therefore at issue in voir dire. The competence issue may arise under the rubric of "juror effectiveness." Assessing effectiveness involves evaluating jury outcomes against some standard of reasonableness and studying how jurors react to information they are given to reach a decision (Pendell 1989). Concern for juror effectiveness led one federal judge, with consent of all parties, to experiment with selecting jurors on the basis of educational background (p.319). Several writers have addressed the jury competence issue, including Kalven and Zeisel (1966), Kalven (1964), Visher (1987), Kadish and Kadish (1971), Scheflin and Van Dyke (1980), Williams (1963) and Greene (1983). Visher (1987) posits the most serious criticism of the jury system is that jurors are not competent to impartially consider evidence and decide issues of fact. As Greene humorously comments," the intellectual incompetence of the civil jury has been vastly exaggerated" (Greene, p. 228).

Implicit in the jury selection process is the assumption that demographic variables, such as ethnicity, national origin, affluence, gender, occupation, urbanization, education and social standing along with jurors' psychographic and attitudinal characteristics influence verdicts. Empirical evidence that jurors' demographic characteristics explain or account for trial outcomes appears mixed.

Changing demographics as "Gen-X"( born between 1965 and 1977) and "Gen- Y" (born after 1977) become members of the venire panel and bring different values, lifestyles and experiences to the jury room merit careful consideration in many civil cases, particularly those related to gender (Baker 2004). Eisenberg and Wells (2002), identify a number of popular beliefs that attorneys presumably hold about the relationship between jury demographics and performance.

Conventional wisdom among attorneys takes two paths. One path is that counties, the usual geo-political level where jury selection occurs, have liberal or conservative predispositions that favor or oppose awards to plaintiffs. The 
second path is that jurors' personal and demographic characteristics influence case outcomes. While attorneys may rely on these two stereotype views, research in support is inconclusive (p.1843). Eisenberg and Wells' overall conclusion is that there is only modest support for the general ability of demographic variables to explain case outcomes. An earlier study by Bornstein and Rajki (1994) reports that on the whole, behavioral variables such as attitude and personality, are stronger predictors of verdicts than demographics (p.130).

Commenting on Eisenberg and Wells(2000), Saks (2002) posits that demographics has little to do with the outcome of civil trials, and is skeptical of whether they were addressing whether a particular community has an idiosyncratic predisposition toward generous awards to plaintiffs or the question of whether particular demographic groups have a like predisposition. If the question is the latter, he argues research offers little support, despite attorney belief to the contrary (p.1881). Hastie et al (1998) for example, found individual differences in jurors' gender, age, education, income and ethnicity were only weakly related to their verdicts. Citing Diamond et al (1998) and Wissler $e t$ al (1999), Saks suggests that the effects of demographics on damage awards were likely minimal (p. 1881). With regard to pain and suffering, income had a statistically significant but small positive effect and gender had a substantial positive effect, with men awarding more.

A mock jury study by Bothwell et al (2006) found racial bias in damage awards but concluded that subtle racial biases operating at the subconscious level probably get washed out in the deliberation process as juries come to agreement on the appropriate award. Examining social status of jurors to update earlier jury studies that found white upper class men dominate jury deliberations, York and Cromwell (2006) found that upper class jurors alone--not men, not whites--have more influence on deliberations. They conclude that statistical representation of demographic groups in the jury pool does not guarantee that diverse views will affect verdicts.

In medical-malpractice and product-liability verdicts Rose and Vidmar (2002) found no difference in awards associated with juror demographics. In a study of large damage cases, Vinson et al (2008) found demographics predicted verdict and award only modestly. In selecting civil juries, Higgins (1998) offers this summary conclusion: "Ask and ye shall predict; good questions beat (demographic) stereotypes when choosing jurors." While good questions and behavioral analysis help choosing jurors, the "jury" is still out regarding demographics.

\section{RESEARCH HYPOTHESES}

These findings from the literature reviewed in the previous section are the basis for the eighteen research hypotheses (six variables and three award recommendations) enumerated in this section. Table 1 summarizes the research hypotheses, stated in the null form, e.g., "recommended award for vehicle damage of any amount is not independent of gender." Each cell in the table indicates a null hypothesis of non- independence (NI) between the variable and the characteristic of interest.

Table 1: Matrix of Research Hypotheses

\begin{tabular}{lccc}
\hline & & Recommended Award \\
\cline { 2 - 4 } Demographic Variable & Vehicle Damage & Medical Expenses & Business Damage \\
\hline Gender & NI & NI & NI \\
Ethnicity & NI & NI & NI \\
Family Income & NI & NI & NI \\
Age & NI & NI & NI \\
Education & NI & NI & NI \\
Civil Suit Experience & NI & NI & \\
\hline
\end{tabular}

\section{THE CASE STUDY}

To test these hypotheses, we presented a written civil case to a random sample of 500 potential jurors. The case concerned an automobile accident. In the case the defendant was clearly at fault for the accident, but the injury, damages and loss were very controversial and at issue. For this case study, each side had expert witnesses (medical doctors and economists) whose testimony supported its position. Directions instructed study participants to read the case as if they 
were members of this jury and to indicate what amount of award, if any, would be fair. The award was broken down into vehicle damages, medical expenses and lost business income (business damages). The defendant rear-ended the plaintiff with damage to the plaintiff's large old van $(\$ 2,000)$ and moderate damage to the defendant's expensive foreign sports car $(\$ 9,000)$. The plaintiff claimed to have suffered back and neck injuries in the automobile accident. He alleged that because of his injuries and pain he could not adequately manage his newly formed manufacturing business, having undergone major surgery to fuse two disks. His medical doctor testified that the plaintiff's injuries and pain were most likely the primary result of the subject motor vehicle accident. The plaintiff's medical bills amounted to $\$ 68,000$.

The defendant's medical doctor testified that the plaintiff's medical condition was the result of a preexisting injury received five years earlier. This doctor's opinion was that the surgery would have been most likely required even without this automobile accident. The plaintiff's economic expert presented a thorough analysis that indicated the plaintiff's start-up business most likely would have been very successful had the plaintiff not been involved in his accident, and estimated that the business suffered damages of $\$ 250,000$. The economist alleged that these damages were the direct result of the plaintiff not being able to personally manage the business and this business's opportunity to succeed was dependent on the plaintiff's direct participation and management. The senior sales manager of the subject business testified that it lost sales and business opportunities because of the plaintiff's inability to be actively and directly involved in its operation. He also testified that he resigned his position and accepted a position with another company because he believed the plaintiff's company would face very difficult times without the plaintiff's direct involvement.

The defense's economic expert presented a much different picture. The expert asserted that the firm was failing prior to the accident and would have most likely failed regardless of the plaintiff's injuries. The expert presented information that the business was in arrears for its taxes and loan even prior to the accident. Also, the defense had the plaintiff's banker give testimony that the bank was very concerned about the future of the company early in its organization because this small bank had loaned it $\$ 400,000$, which was the bank's largest loan.

\section{METHODOLOGY}

Five hundred residents of South Louisiana comprised a stratified random sample who received the case study and survey instrument personally or by mail. The sample was designed by separating the population into strata according to demographics and then selecting a simple random sample from each stratum to ensure the study included all demographic groups. Two hundred thirty seven of the sample size of $500(47.4 \%)$ provided a usable completed questionnaire. The completed questionnaires were fairly evenly distributed along the lines of the demographics of the population for sex, race, educational, age and income (See TABLES I through V for selective demographics counts).

In addition to asking for demographic data, the instrument also contained questions concerning whether the respondent had ever been a party to a personal injury lawsuit or closely known someone who had been, and whether they or their acquaintances were plaintiffs or defendants. (See TABLE VI).

The sample was then analyzed based on the simulated jurors' individual characteristics and their answers to the questionnaire using Chi Square contingency tables.

Table I

Race By Sex

\begin{tabular}{lcccc}
\hline Race/ Sex & Total & African/Americans & White & Other \\
Male & 111 & 31 & 61 & 19 \\
Female & 126 & 33 & 76 & 17 \\
Total & 237 & 64 & 137 & 36 \\
\hline
\end{tabular}


Table II

Race By Age

\begin{tabular}{llccc}
\hline Race/Age & Total & African/Americans & White & Other \\
& & & 39 & 12 \\
Under 30 & 61 & 18 & 29 & 8 \\
30 to 40 & 56 & 14 & 31 & 6 \\
40 to 50 & 51 & 12 & 38 & 10 \\
Over 50 & 69 & 20 & & 36 \\
Total & 237 & 64 & 137 & 36 \\
\hline
\end{tabular}

Table III

Race By Sex By Age

\begin{tabular}{|c|c|c|c|c|}
\hline Race/Age & Total & African/Americans & White & Other \\
\hline \multicolumn{5}{|l|}{ Female } \\
\hline Under 30 & 33 & 8 & 19 & 6 \\
\hline 30 to 40 & 29 & 6 & 15 & 8 \\
\hline 40 to 50 & 26 & 7 & 18 & 1 \\
\hline Over 50 & 38 & 12 & 24 & 2 \\
\hline Total & 126 & 33 & 76 & 17 \\
\hline \multicolumn{5}{|l|}{ Male } \\
\hline Under 30 & 28 & 8 & 14 & 6 \\
\hline 30 to 40 & 27 & 7 & 13 & 7 \\
\hline 40 to 50 & 25 & 5 & 17 & 3 \\
\hline Over 50 & 31 & 11 & 17 & 3 \\
\hline Total & 111 & 31 & 61 & 19 \\
\hline
\end{tabular}

Table IV

Sex By Education

\begin{tabular}{|c|c|c|c|}
\hline Race/Age & Total & Female & Male \\
\hline$<12$ Grade & 24 & 7 & 17 \\
\hline HS Graduate & 94 & 51 & 43 \\
\hline Some College & 59 & 37 & 22 \\
\hline College Graduate & 39 & 22 & 17 \\
\hline Post Undergraduate & 21 & 9 & 12 \\
\hline Total & 237 & 126 & 111 \\
\hline \multicolumn{4}{|c|}{$\begin{array}{c}\text { Table V } \\
\text { Family Income }\end{array}$} \\
\hline Annual Family Income/ & & Total & \\
\hline$<\$ 16,000$ & & 9 & \\
\hline$\$ 16,001$ to $\$ 30,000$ & & 23 & \\
\hline$\$ 30,001$ to $\$ 60,000$ & & 96 & \\
\hline$\$ 60,001$ to $\$ \$ 100,000$ & & 62 & \\
\hline Over $\$ 100,000$ & & 47 & \\
\hline Total & & 237 & \\
\hline
\end{tabular}


Table VI

Has Been Involved In A Personal Injury Suit Or Knows Someone Well Who Has

\begin{tabular}{llll} 
& Yes & No & Total \\
Male & 68 & 43 & 111 \\
Female & 74 & 52 & 126 \\
\cline { 2 - 4 } & 142 & 95 & 237
\end{tabular}

\section{RESULTS}

The answers given by women are the most interesting, significant and were not expected and thus are the central part of this section's coverage (See Table VII). The other basic demographics were not remarkable and did not show differences in results award. The least anticipated finding was that young (under 30 years of age) white women were not inclined to provide any economic award to the plaintiff and when they did, it was significantly smaller than any other demographic group. This respondent cluster was the only group that had more than one participant answer that the plaintiff should not even get the total value of his vehicle damages. After evaluating their remarks from the open-ended comments section of the questionnaire, a possible explanation for the young white women's position is that the plaintiff should not have brought the suit against the defendant and should suffer for it. A Chi Square test was performed to determine if white women's responses differ from African American and Other women for the vehicle damage award. The hypothesis (for women) of independence is rejected and it is concluded that a vehicle damage award for any amount (if at all) is quite probably dependent on race $\left(\mathrm{X}^{2}=32>\mathrm{X} 2=.99(4)=13.3\right)$.

Table VII

Vehicle Damage Award By Female

\section{Classification}

White Women under 30 White Women 30 to 40 White Women 40 to 50 White Women over 50 A.A.* Women under 30 A.A. Women 30 to 40 A.A. Women 40 to 50 A.A. Women over 50 Other Women under 30 Other Women 30 to 40 Other Women 40 to 50 Other Women over 50

* African/American

\section{Award}

\begin{tabular}{cccc} 
No Award & Some Award & Total Award & Total \\
5 & 7 & 7 & 19 \\
0 & 4 & 11 & 15 \\
0 & 3 & 15 & 18 \\
0 & 4 & 20 & 24 \\
1 & 0 & 7 & 8 \\
0 & 0 & 6 & 6 \\
0 & 1 & 6 & 7 \\
0 & 2 & 10 & 12 \\
0 & 0 & 6 & 6 \\
1 & 1 & 6 & 8 \\
0 & 0 & 1 & 1 \\
0 & 0 & 2 & 2 \\
\hline
\end{tabular}

$\begin{array}{lll}7 & 22 & 96\end{array}$ 126

Table VII

Vehicle Damage Award By Females

\begin{tabular}{ccccc}
\hline & Award & & & \\
\hline & No Award & Some Award & All & Total \\
White Women & 8 & 20 & 49 & 77 \\
A.A.* Women & 0 & 3 & 29 & 32 \\
Other Women & 0 & 1 & 16 & 17 \\
\cline { 2 - 5 } Total & 8 & 24 & 94 & 126 \\
\hline
\end{tabular}


White women overall were the least generous in making any award. Non-white women of all ages overwhelmingly favored an award for not only the vehicle damage, but for the plaintiff's medical expenses and for some amount for the business damages (SEE TABLES VIII and IX). A Chi Square test was performed and the two hypotheses (for women) of independence is rejected and it is concluded that a medical expense award $\left(X^{2}=69.9>X 2=.99(4)=13.3\right)$ and the business damage award $\left(\mathrm{X}^{2}=33>\mathrm{X} 2=.99(4)=13.3\right)$ is quite probably dependent on race.

Table VIII

Medical Expense Award By Females

\begin{tabular}{lcccc} 
Classification & Award & & & \\
\hline \\
White Women & No Award & Some Award & All & Total \\
A.A.*Women & 22 & 28 & 27 & 77 \\
Other Women & 1 & 4 & 27 & 17 \\
$\quad$ Total & 0 & 3 & 14 & 126 \\
\cline { 2 - 5 } & 8 & 24 & 94 &
\end{tabular}

Table IX

Business Damages Award By Females

\begin{tabular}{|c|c|c|c|c|}
\hline Classification & Award & & & \\
\hline & No Award & Some Award & All & Total \\
\hline White Women & 40 & 21 & 27 & 16 \\
\hline A.A.* Women & 3 & 10 & 19 & 32 \\
\hline Other Women & 1 & 5 & 11 & 17 \\
\hline Total & 8 & 24 & 94 & 126 \\
\hline
\end{tabular}

* African/American

The non-white classification awarded a larger total dollar value for each damage groups (vehicle, medical and business) and total than the white group. A t-test was performed and the differences was significant at the .01 level. Also, the non-white women gave the overall largest average award (SEE TABLE XI). Some respondents gave a total award larger than the total sought $(\$ 320,000)$.

Table XI

Dollar Average For Total Award

\begin{tabular}{lcc}
\hline Classification & Average Award & Compared to Average \\
\hline White Women & $\$ 72,124$ & $-\$ 43,863$ \\
A.A.* Women & $\$ 182,333$ & \\
Other Women & $\$ 159,984$ & \\
White Men & $\$ 119,965$ \\
A.A. Men & $\$ 144,331$ \\
Other Men & $\$ 154,111$ \\
& $\$ 115,987$ \\
Total Weighted Average &
\end{tabular}




\section{CONCLUSIONS}

Whether or not demographic factors significantly influence jurors' judgment still remains a question to be resolved with additional research. In particular, further research is needed to assess the interrelationships between salient juror characteristics, including demographics, and the extent to which they are moderated by other individual characteristics including personality, psychographic and lifestyle factors in jurors' decision making and deliberation processes. Of course the participants of this study were not members of a live jury in a real court room deciding a verdict. A case study such as this cannot replicate the dynamics of a jury trial or what takes place in the jury deliberations or even the dynamics of a controlled mock jury experiment. Despite these limitations, the findings of this case study indicate that certain demographics may influence a person's penchant for deciding personal injury awards and suggests that that certain demographics groups may have a more liberal or open mind to granting a personal injury award while others have a predisposition to be conservative in awards. In any event attorneys who are armed with objective information about possible leanings of particular demographic groups can complement the voir dire process with enlightened follow-up. Any resulting advantage, however slight will inure to the benefit of the side that best uses the information in seating jurors favoring their arguments.

\section{AUTHOR INFORMATION}

Dr. James H. Underwood III is associate professor of marketing in the department of Marketing and Hospitality at the University of Louisiana, Lafayette. He has numerous publications in marketing and business journals and professional association proceedings. He has served as expert witness in many business loss and personal Injury cases. Among his research Interests are forensic marketing and economic analysis, marketing management, distribution, marketing research methods, and marketing engineering.

Dr. Denis Boudreaux is an associate professor of finance at the University of Louisiana at Lafayette. His research interests include forensic economics, capital market efficiency and energy economics. Dr. Boudreaux has published over twenty articles in refereed journals and has presented academic papers to national and international conferences. $\mathrm{He}$ is a forensic economist and testifies as an expert witness in the areas of personal injury, wrongful death, discrimination, commercial damages and firm valuation.

Dr. S.P. Uma Rao's research interests lie in two quite different fields, primarily, in the field of Investments, especially asset pricing, portfolio theory, optimization, capital market efficiency and evaluation of Mutual funds. Rao also has research interest in finance decision support system, especially application of simulation, linear programming and other tools to financial modeling. Rao has published research articles in Journals such as Journal of Business Ethics, Global Finance Journal, Managerial Finance, Southwestern Economic Review, Journal of Economics and Finance, International Business \& Economics Research Journal, Journal of Business and Society, Journal of Accounting and Finance Research.

\section{REFERENCES}

1. Alschuler, A. W. (1989). "The Supreme Court and the Jury: Voir Dire, Preemptory Challenges, and the review of Jury Verdicts." University of Chicago Law Review 56.

2. Baker, K., D. (2004). "Jury Selection Landmines - Sexual Harassment Allegations, Corporate Judgments and Punitive Damages ." FDCC Quarterly 54(2): 133-152.

3. Bonora, B. and E. Krauss, Eds. (1979). Jurywork, Systematic Techniques : A Manual for Lawyers, Legal Workers and Social Scientists National Jury Project. Berkeley, CA:The Project.

4. Bornstein, B. H. and M. Rajki (1994). "Extra-Legal Factors and Product Liability: The Influence of Mock Jurors' Demographic Characteristics and Intuitions about the Cause of an Injury." Behavioral Sciences \& the Law 12(2): 127-147.

5. $\quad$ Bothwell, R. K., M. A. Pigott, et al. (2006). "Racial Bias in Juridic Judgment at Private and Public Levels." Journal of Applied Social Psychology 36(9): 2134-2149.

6. $\quad$ Breheney, C., J. Groscup, et al. (2007). "Gender Matters In The Insanity Defense." Law \& Psychology Review 31: 93-123.

7. $\quad$ Diamond, S. S. and e. al (1998). "Juror Judgments about Liability and Damages: Sources of Variability and Ways to Increase Consistency." DePaul Law Review 48: 303-06. 
8. $\quad$ Eisenberg, T. and M. T. Wells (2002). "Trial Outcomes and Demographics: Is there a Bronx Effect?" Texas Law Review 80(7): 1839-175.

9. $\quad$ Faringer, H. P. (1980). "In the Valley of the Blind: A Primer on Jury Selection in Criminal Cases." Law and Contemporary Problems 43(4 ): 116-136.

10. Ginger, A. (1979). Jury Selection in Criminal Trials.

11. Golding, J., M, J. Yozwiak, A, et al. (2005). "The Effect of Gender in the Perception of Elder Physical Abuse in Court." Law and Human Behavior 29(5): 605.

12. Golding, J. M., G. S. Bradshaw, et al. (2007). "The Impact of Mock Jury Gender Composition on Deliberations and Conviction Rates in a Child Sexual Assault Trial." Child Maltreatment 12(2): 182-190.

13. Greene, E. (1989). "On Juries and Damage Awards: The process of Decision making." Law and Contemporary Problems 52(4): 225-246.

14. Hans, V. and N. Vidmar (1982). Jury Selection. New York, Academic Press.

15. Hastie, R., S. Penrod, et al. (1983). Inside the Jury. Cambridge, Harvard University Press.

16. Hastie, R., D. A. Schkade, et al. (1998). "A Study of Juror and Jury Judgments in Civil Cases: Deciding Liability for Punitive Damages." Law and Human Behavior 22(3): 287-314.

17. Hepburn, J. (1980). "The Objective Reality of Evidence and the Utility of Systematic Jury Selection." Law and Human Behavior 4: 89-101.

18. Higgins, M. (1998). "Ask and ye shall predict." ABA Journal 84: 16.

19. Higgins, P. L., W. P. Heath, et al. (2007). "How Type of Excuse Defense, Mock Juror Age, and Defendant Age Affect Mock Jurors' Decisions." Journal of Social Psychology 147(4): 371-392.

20. $\quad$ Johnson, S. L. (1985). "Black Innocence and the White Jury." Michigan Law Review 83.

21. Kadish, M. and S. Kadish (1971). "The Institutionalization of Conflict: Jury Acquittals." Journal of Social Issues 27: 199-217.

22. $\quad$ Kalven, H. (1964). "The Dignity of the Civil Jury." Virginia Law Review.

23. Kalven, H. and H. Zeisel (1966). The American Jury.

24. Kennedy, R. (1994). "The state, criminal law, and racial discrimination: A comment." Harvard Law Review 107(6): 1255-1259.

25. Kennelly (1965). Jury Selection in a Civil Case, 9 Trial Law Guide 15.

26. King, N. J. (1991). "Post conviction Review of Jury Discrimination: Measuring the Effect of Race of Juror on Jury Decisions." Michigan Law Review 92(1): 63-130.

27. Krieger, L. H. (1995). "The Content of Our Categories: A Cognitive Bias Approach to Discrimination and Equal Opportunity." Stanford Law Review 47: 1161-1188.

28. Lipton, J. P. (1983). "Racism in the Jury Box: the Hispanic Defendant." Hispanic Journal of Behavioral Sciences 5: 275-.

29. Miller, M. and J. Hewett (1978). "Conviction of a Defendant as a Function of Juror-Defendant Similarity." Journal of Social Psychology 105(3): 159-161.

30. Mills, C. J. and W. E. Bonahan (1980). "Jury Characteristics: To What Extent are they Related to Verdicts?" Judicature 64: 22-27.

31. Pendell, J. W. (1989). "Enhancing juror Effectiveness: An Insurer's Perspective." Law and Contemporary Problems 52(4): 311-321.

32. $\quad$ Pennington, N. and R. Hastie (1991). "A Cognitive Theory of Juror Decision Making: The Story Model." Cardozo Law Review 13: 518-520.

33. Rose, M., R. and N. Vidmar (2002). "The Bronx "Bronx jury": A profile of Civil Jury Awards in New York Counties." Texas Law Review 80(7): 1889-1898.

34. Saks, M. J. (2002). "Trial Outcomes and Demographics: Easy Assumptions versus Hard Evidence." Texas Law Review 80(7): 1877.

35. Scheflin, A. and J. Van Dyke (1980). "Jury Nullification: The Contours of Controversy." Law and Contemporary Problems 43: 52-115.

36. Schulman (1973). "A Systematic Approach to Successful Jury Selection, 2 Guild Notes."

37. Taylor-Thompson, K. (2000). "Empty Votes in Jury Deliberations." Harvard Law Review 113(6): 1261-1320.

38. Turner, C. (1996). "What's the Story? An Analysis of Juror Discrimination and a Plea for Affirmative Jury Selection." American Criminal Law Review 34(1(fall 1996)): 289-323.

39. Ugwuegbu, D. (1973). "Racial and Evidentiary Factors in Juror Attribution of Legal Responsibility." Journal of Experimental Social Psychology 15(133): 141-145. 
40. Ugwuegbu, D. (1979). "Racial and Evidential Factors in Juror Attribution of Legal Responsibility." Journal of Experimental Social Psychology 133: 133-146.

41. Underwood, B. J. (1992). "Ending Race Discrimination in Jury Selection: Whose Right is it anyway?" Columbia Law Review 92: 726-750.

42. Vinson, K. V., M. Costanzo, A., et al. (2008). "Predictors of verdict and punitive damages in high-stakes civil litigation." Behavioral Sciences \& the Law 26(2): 167.

43. Visher, C. A. (1987). "Juror Decision Making: The Importance of Evidence." Law and Human Behavior 11(1): $1-17$.

44. Williams, G. (1963). The Proof of Guilt. London, Stevens Press.

45. Wissler, R. E., A. J. Hart, et al. (1999). "Decision making About General Damages: A Comparison of Jurors, Judges, and Lawyers." Michigan Law Review 98 .

46. $\quad$ York, E. and B. Cornwell (2006). "Status on Trial: Social Characteristics and Influence in the Jury Room." Social Forces 85(1): 455-477.

\section{NOTES}

